\title{
Effect of the standardized Cimicifuga foetida extract on Hsp 27 expression in the MCF-7 cell line
}

\author{
Maritza C Soler ${ }^{1}$, Jessica L Molina ${ }^{2}$, Hugo A Díaz ${ }^{3}$, Vivian C Pinto ${ }^{4}$, Yasenka L Barrios ${ }^{5}$, Kan $\mathrm{He}^{6}$, Marc Roller ${ }^{7}$, \\ Caroline R Weinstein-Oppenheimer ${ }^{5}$
}

1 Departamento de Química y Bioquímica, Facultad de Ciencias, Universidad de Valparaíso.

${ }^{2}$ Carrera de Tecnología Médica, Facultad de Medicina, Universidad de Valparaíso.

${ }^{3}$ Departamento de Biología y Ciencias Ambientales, Facultad de Ciencias, Universidad de Valparaíso.

${ }^{4}$ Carrera de Química y Farmacia, Facultad de Farmacia, Universidad de Valparaíso.

${ }^{5}$ Departamento de Bioquímica, Facultad de Farmacia, Universidad de Valparaíso, Valparaíso, Chile.

${ }^{6}$ Department of Research and Development, Naturex, Inc. South Hackensack, New Jersey 07606, USA.

${ }^{7}$ Naturex SA, Site d'Agroparc BP 1218, 84911 Avignon Cedex 9, France.

\begin{abstract}
Cimicifuga foetida, an Asian Cimicifuga species, has been employed as a cooling and detoxification agent in traditional Chinese medicine since ancient times. For this herb, two cycloartane triterpene glycosides isolated from the rhizomes have demonstrated cytotoxicity on rat tumor and human cancer cell lines. Since human Hsp27 is increased in various human cancers and exhibits cytoprotective activity that affects tumorigenesis and the susceptibility of tumours to cancer treatment, the purpose of this research was to study the expression of this protein in MCF-7 breast cancer cells. To accomplish this aim, MCF-7 cells were exposed to different concentrations of Cimicifuga foetida extract showing a reduction in cell number measured by the sulforhodamine assay. In addition, the expression of Hsp-27 mRNA detected by RT-PCR and Hsp-27 protein detected by immnofluorescence was present in all conditions, except when using the highest concentration of Cimicifuga foetida extract $(2,000 \mu \mathrm{g} / \mathrm{L})$. We conclude that Hsp 27 expression at 2,000 $\mu \mathrm{g} / \mathrm{L}$ Cimicifuga foetida extract is diminished. This is the first report showing the Hsp-27 expression after exposure to Cimicifuga foetida extract in MCF-7 cells.
\end{abstract}

Key terms: Cimicifuga foetida, cytotoxicity, Hsp-27, Immunofluorescence, MCF-7 cells, RT-PCR.

\section{INTRODUCTION}

There is a great need to improve cancer therapies through the search for new medicines with anticancer properties. The herbs used in traditional medicine for cancer treatment are promising candidates.

The genus Cimicifuga (Ranunculaceae) consists of more than 18 species whose roots and rhizomes have been widely used in traditional medicine worldwide (Tian et al., 2007). Cimicifuga racemosa, (syn. Actea racemosa) a famous North American species has shown remarkable antitumor activities in diverse studies. Extracts from black cohosh (C. racemosa) have been traditionally used by Native Americans for the treatment of rheumatism, dyspepsia, epilepsy, kidney ailments, dysmenorrhoea and the relief of pain during menses and childbirth (Borrelli and Ernst, 2002). The roots and rhizomes of these plants contain two major classes of compounds, triterpene glycosides and phenylpropanoids (Einbond et al., 2008). For this perennial herb, it has been demonstrated antiproliferative effects, induction of cell cycle arrest and apoptosis in the breast cancer cell line, MCF-7 (Hostanska et al., 2004a, b). Several kinds of extracts from rhizomes of $C$. racemosa were demonstrated the capabilities of killing estrogen receptor-positive (MCF-7), estrogen receptor-negative (MDAMB231 and MDA-MB-453) human breast carcinoma and androgen-sensitive LNCaP human prostate cancer-derived cell lines (Einbond et al., 2004; Hostanska et al., 2004a, 2005; Jarry et al., 2005; Seidlova-Wuttke et al., 2006).
C. foetida, an Asian Cimicifuga species, has been employed as a cooling and detoxification agent in traditional Chinese medicine since ancient times (Tian et al., 2007). Recently, two cycloartane triterpene glycosides isolated from the rhizomes of $C$. foetida, have demonstrated cytotoxicity on the Ehrlich ascites carcinoma (EAC) rat tumor cell line and on SGC7901 and MDA-MB-A231 human cancer cell lines (Sun et al., 2007).

Heat shock proteins (Hsps), which are molecular chaperones, appeared overexpressed and implicated in tumor cell proliferation, metastasis and death. Hsp 27 is a family member of the small heat shock proteins (sHsps), which represent an abundant and ubiquitous family of stress proteins with a monomeric mass ranging between 15 and $30 \mathrm{kDa}$ (Parcellier et al., 2005). This protein has been associated with $\alpha$ estrogen receptors (Er $\alpha$ ) in female breast carcinomas and endometrial carcinomas, but not associated with Ero in male breast carcinomas, cervical uterine carcinomas, hepatocellular carcinomas and meningiomas, tissues that may express Ero (Ciocca and Calderwood, 2005).

Since human Hsp27 is increased in various human cancers and exhibits cytoprotective activity that affects tumorigenesis and the susceptibility of tumors to cancer treatment (Fortin et al., 2000), it is interesting to study the expression of this protein in MCF-7 breast cancer cells.

Hsp27 protein and mRNA levels are induced by heat shock, $\beta$-estradiol and antagonists of the estrogen receptor such as ICI 164,384, tamoxifen and hidroxi-tamoxifen in estrogen 
receptor positive MCF-7 cells, while its expression is lower when exposed to dioxins as 2,3,7,8-tetrachlorodibenzo-p-dioxin (Edwards et al., 1981; Porter et al., 2001).

Considering that $C$. foetida contains similar triterpenoids and also the reported antitumor activity of C. racemosa (Tian et al., 2007), we performed experiments to detect the expression of Hsp-27 in MCF-7 cells treated with different concentrations of $C$. foetida extract (CFE) and report the results herein.

\section{MATERIALS AND METHODS}

Chemicals and Reagents

All chemicals were reagent or molecular biology grade. $\beta$-estradiol stock was $0.2 \mathrm{mM}$ in ethanol, tamoxifen stock was $1 \mathrm{mg} / \mathrm{mL}$ in ethanol and C. foetida extract (CFE) stock was 0.1 $\mathrm{g} / \mathrm{L}$ in phosphate buffer saline (PBS). All stock solutions were kept at $-20^{\circ} \mathrm{C}$.

Plant materials

Commercial dried powder of C. foetida was obtained from Stryka Botanics (lot BC031021) and the species qualification was performed using high performance liquid chromatography (HPLC) with evaporative light scattering detection (ELSD) for fingerprint analysis.

\section{Cell culture}

The human breast adenocarcinoma cell line MCF-7 (American type culture collection, Rockville, MD, USA) was grown in DMEM (Invitrogen, Carlsbad, CA, USA) supplemented with $10 \%$ fetal bovine serum (FBS, PAA Laboratories $\mathrm{GmbH}$, Linz, Austria), 2mM glutamine, 10U/L penicillin and $100 \mu \mathrm{g} /$ $\mathrm{mL}$ streptomycin. The cells were cultured in a humidified incubator with a $5 \% \mathrm{CO}_{2}$ atmosphere.

Phenol red free media with $10 \%$ activated charcoaladsorbed FBS to remove steroids, was used in all experiments to expose the MCF-7 cells to $\beta$-estradiol, tamoxifen and CFE. This media was also used as the control condition in all the experiments.

\section{Sulforhodamide assay}

MCF-7 cells were trypsinized and 5,000 cells/well seeded in 96-well plates. Selected dilutions of CFE, tamoxifen and $\beta$-estradiol, were then added 24 hours after cell seeding and cells were incubated for an additional two days. Each treatment was performed in triplicate. After this, the treatmentcontaining media was removed and fresh media was added to allow the remaining viable cells to proliferate. One day later, the cells were fixed by precipitation with $60 \%$ tricloroacetic acid for one hour. After extensive washing with water, the cells were stained with $0.4 \%$ sulforhodamine in $1 \%$ acetic acid, for 10 minutes and extensively washed with $1 \%$ acetic acid, then the plates were air-dried and the dye solubilized in $10 \mathrm{mM}$ Trizma Base. The optical density was read in a Merckscan (Anthos Labtec Instruments, Salzburg, Austria) plate reader at $540 \mathrm{~nm}$. Survival was calculated by subtraction of the optical densities of the control condition from the experimental condition (Skehan et al., 1990). Negative values mean death or proliferation inhibition.

\section{RNA Isolation}

Total cellular RNA was isolated utilizing the Trizol (Invitrogen) method. The cells were directly lysed with $1 \mathrm{ml}$ TRIZOL reagent per $1 \mathrm{~cm}^{2}$ of cell culture surface, following the manufacturer instructions. The RNA pellets were air dried and resuspended in 50-100 $\mu \mathrm{L}$ of diethyl pyrocarbonate treated ultrapure water (0.01\% DEPC, Sigma). The yield and purity of the isolated RNAs were determined in a NanoDrop spectrophotometer. The RNA was kept at $-70^{\circ} \mathrm{C}$ until used.

Primers for the RT-PCR reactions

The primers for the $\beta_{2}$ microglobulin RT-PCR reactions were those published by Laffon et al (2001). The sequences were 5 'CCA GCA GAG AAT GGA AAG TC3` for sense and 5 'GAT GCT GCT TAC ATG TCT CC ${ }^{`}$ for antisense primers.

The primers for the Hsp-27 RT-PCR reactions were those published by Cubano and Lewis (2001). The sequences were 5`TGT CCC TGG ATG TCA ACC ACT TC3` for sense and 5`AAA AGA ACA CAC AGG TGG CGG3` for antisense primers.

Reverse transcriptase reaction

The reaction was performed using $0.5 \mu \mathrm{g}$ of primer for $1.0 \mu \mathrm{g}$ RNA and following the directions of the manufacturer for AMV reverse transcriptase (Promega).

Polymerase Chain Reaction

In the same reaction tube used for the cDNA synthesis, the following reaction mixture was added: $4.6 \mu \mathrm{L} \mathrm{MgCl}_{2}(25 \mathrm{mM})$, $4 \mu \mathrm{L}$ PCR buffer 10X (Promega), $6.4 \mu \mathrm{L}$ dNTPs mixture $(1.25 \mathrm{mM}$ each), $4 \mu \mathrm{L}$ of sense and $4 \mu \mathrm{L}$ anti-sense primers (10 $\mu \mathrm{M}$, each), $0.5 \mu \mathrm{L}$ Taq DNA polymerase (2,5 U. Promega) and ultrapure/ DEPC water to complete $40 \mu \mathrm{L}$. For Hsp-27 its specific primers were used and the following program in a Thermo PXE 0.5 Thermocycler: an initial 3 minutes step at $95^{\circ} \mathrm{C}, 30$ cycles of 1.5 minutes at $95^{\circ} \mathrm{C}, 1$ minute at $56^{\circ} \mathrm{C}, 2$ minutes at $72^{\circ} \mathrm{C}$ and a final step of 5 minutes at $72^{\circ} \mathrm{C}$. For $\beta_{2}$ microglobulin, the same reaction mixture was used with its specific primers and the following program in a Thermo PXE 0.5 Thermocycler: an initial 5 minute step at $95^{\circ} \mathrm{C}, 30$ cycles of 45 seconds at $95^{\circ} \mathrm{C}, 35$ seconds at $56^{\circ} \mathrm{C}, 1$ minute at $72^{\circ} \mathrm{C}$ and a final step of 1 minute at $72^{\circ} \mathrm{C}$.

\section{Detection of Hsp-27 by Immunofluorescence}

MCF-7 cells were grown on silanized slides immersed in cell culture medium inside Petri plates. Before reaching confluence, the cells were exposed for 24 hours to phenol red free media with $10 \%$ activated charcoal adsorbed FBS. Then, the cells were grown for 48 hours in cell culture media containing either CFE $(2,000,200,20$ or $2 \mu \mathrm{g} / \mathrm{L})$, or ßestradiol $(325 \mathrm{pM})$, or tamoxifen $(240 \mathrm{ng} / \mathrm{mL})$ or phenol red free media $10 \%$ adsorbed FBS. To fix the cells on the slides, $4 \%$ p-formaldehide in PBS was used for twenty minutes at $4^{\circ} \mathrm{C}$.

Anti-Hsp-27 c-20 (sc-1048 goat polyclonal antibody raised against Hsp-27 of human origin, Santa Cruz Biotechnology, Inc.) in a 1:50 dilution in PBS was utilized as the primary antibody. 
As secondary antibody, donkey anti-goat IgG-FITC (sc 2024, Santa Cruz Biotechnology, Inc) was used in a 1:100 dilution in PBS. The mounting medium was VectashieldDapi (4,6-diamidino-2-phenylindole) to stain the nuclei (UltraCruz ${ }^{\mathrm{TM}}$ Mounting Medium: sc 24941). All samples were visualized with an Olympus BX 51 Fluorescence microscope provided with a U-MWU2 Olympus filter. Most of the images were taken at a magnification of $40 \mathrm{X}$, except for the control and CFE $200 \mu \mathrm{g} / \mathrm{L}$, to privilege a better image of the immunofluorescence.

Western blot Analysis

Pre-confluent cells were lysed in lysis buffer $(20 \mathrm{mM}$ Tris, $\mathrm{pH}$ 7,5; 5 mM EDTA, $1 \%$ Triton X-100) containing Halt ${ }^{\mathrm{R}}$ Protease Inhibitor Cocktail Kit (Pierce, Rockford, Il, USA). The lysate equivalent to $20 \mu \mathrm{g}$ (Hsp27) or $40 \mu \mathrm{g}$ (actin) of protein was electrophoresed in a $10 \%$ poliacrilamide gel. The proteins were electrotransferred to a PVDF membrane, using an electroblot semi-dry apparatus (BIO RAD). The membranes were blocked overnight with blocking solution (2\% BSA in TBST: $25 \mathrm{mM}$ Tris, $\mathrm{pH} 8.0 ; 125 \mathrm{mM} \mathrm{NaCl}, 0.1 \%$ Tween 20). The membranes were then incubated for 2 hours with the primary antibody, antiHsp27 c-20 (sc-1048 goat polyclonal antibody raised against Hsp-27 of human origin, Santa Cruz Biotechnology, Inc.) (Fig. 5A) or anti-actin c-11 (sc-1615 goat policlonal IgG, Santa Cruz Biotechnology, Inc.)(Fig. 5A), diluted 1:5,000 in blocking solution and after three five-minute washes with TBST, they were incubated for 2 hours in secondary antibody donkey anti- goat IgG-AP (sc-2022 linked to alkaline phosphatase, Santa Cruz Biotechnology, Inc.) (1:10,000 in blocking solution). After three five-minute washes with TBST, an alkaline phosphatase reaction was performed utilizing the Western Blue ${ }^{\mathrm{R}}$ Stabilized substrate for Alkaline Phosphatase (Promega). The blots were scanned and subjected to densitometry analysis. The signals for Hsp27 were normalized against the actin signal for each condition.

\section{RESULTS}

Fingerprinting of the Cimicifuga foetida extract

The extract was analyzed by HPLC with ELSD detector. The chromatogram obtained shows a typical rhizomes and roots of C. foetida profile (Fig. 1). The analysis confirmed by LC/MS detected cimifugin and cimifugin glycoside, which are marks of Asian Cimicifuga species (He et al., 2006).

\section{Cell growth}

Using the sulforhodamine assay, the effect of the CFE (Fig. 2A) on cell growth was assessed and compared to the known effect of the SERM tamoxifen (Fig. 2B). The results of this assay are presented as dot graphics, in which each dot represents the difference between the OD of the cells grown under the experimental condition and cells grown in control cell culture. Every dot under the zero line represents cell death. The cell number progressively diminishes at 24,48 and 72 hours of

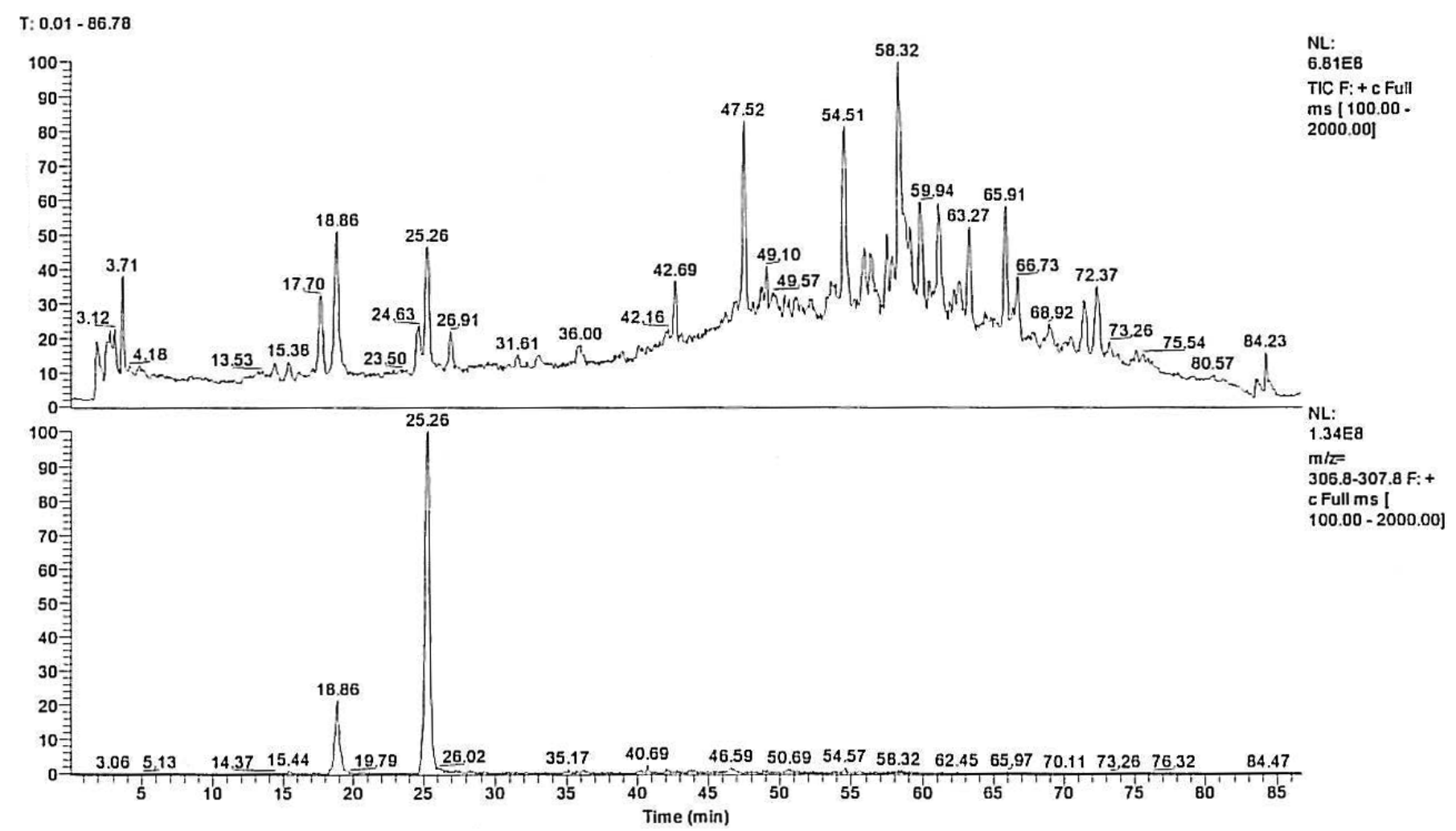

Figure 1: Fingerprinting of the Cimicifuga foetida extract. HPLC-ELSD fingerprint chromatogram of CFE showing a typical C foetida profile (top). LC-MS analysis confirms this Asian species by detection of cimifugin and its glucoside (bottom). 
culture in the presence of $2,000 \mu \mathrm{g} / \mathrm{L}$ of the CFE (Fig. 2A). This is comparable to the effect observed for tamoxifen $(480 \mathrm{ng} / \mathrm{mL})$ on the same experimental setting (Fig. 2B).

Hsp 27

Hsp 27 was detected through RT-PCR for mRNA and by immunofluorescence and Western blotting for protein detection. RT-PCR analysis revealed that the message for Hsp27 did not change when MCF-7 cells were grown in either control media (Fig. 3A, lane 1), CFE 2, 20, $200 \mu \mathrm{g} / \mathrm{L}$ (Fig. 3A, lanes 2, 3 and 4), tamoxifen (Fig. 3A, lane 7), or $\beta$-estradiol (Fig. 3A, lane 8). However, when MCF-7 cells were grown in the presence of $2,000 \mu \mathrm{g} / \mathrm{L}$ of CFE, the message for Hsp 27 was not detectable (Fig. 3A, lane 6). The RT-PCR analysis for the constitutive gene $\beta_{2}$ microglobulin for each cell culture condition is shown in Figure 3B.
Interestingly, the immunofluorescence analysis showed that the expression of Hsp27 at the protein level was undetectable only when the cells were grown on CFE 2,000 $\mu \mathrm{g} / \mathrm{L}$ (Fig. 4). Western blot analysis showed protein expression for cells cultivated in the presence of all concentrations of CFE (Fig. 5A). Densitometry analysis showed a modest reduction in Hsp27 expression as compared to control or $\beta$-estradiol grown cells (Fig. 5B).

\section{DISCUSSION}

We first evaluated the activity of the C. foetida extract (CFE) using a proliferation assay and the result showed a reduction in MCF-7 cell number (Fig. 2). This result is in agreement with a previous report using black cohosh extracts that displayed growth inhibitory activity in MCF-7 (Gaube et al 2007) and in MDA-MB-453 human breast cancer cells (Einbond et al 2008).
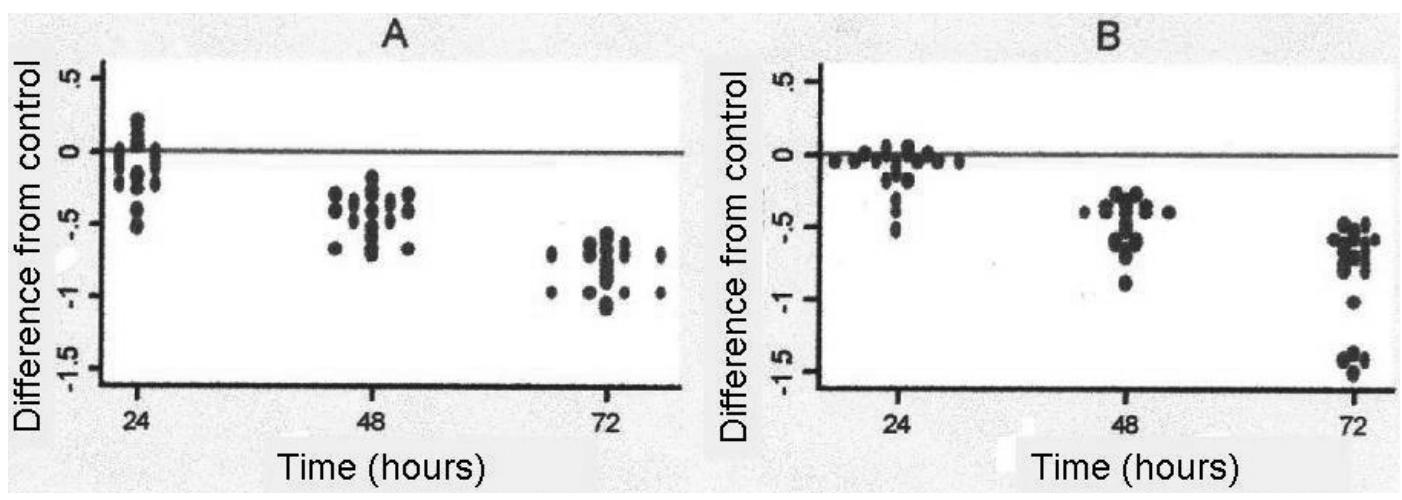

Figure 2: Cimicifuga foetida cytoxicity on MCF-7 cells. Sulforhodamine assay for MCF-7 cells grown in cell culture media containing tamoxifen (Panel A) or Cimicifuga foetida extract (Panel B) for different time periods. Each dot represents the difference between the absorbance registered for cells grown under experimental conditions and control conditions for an individual replicate.
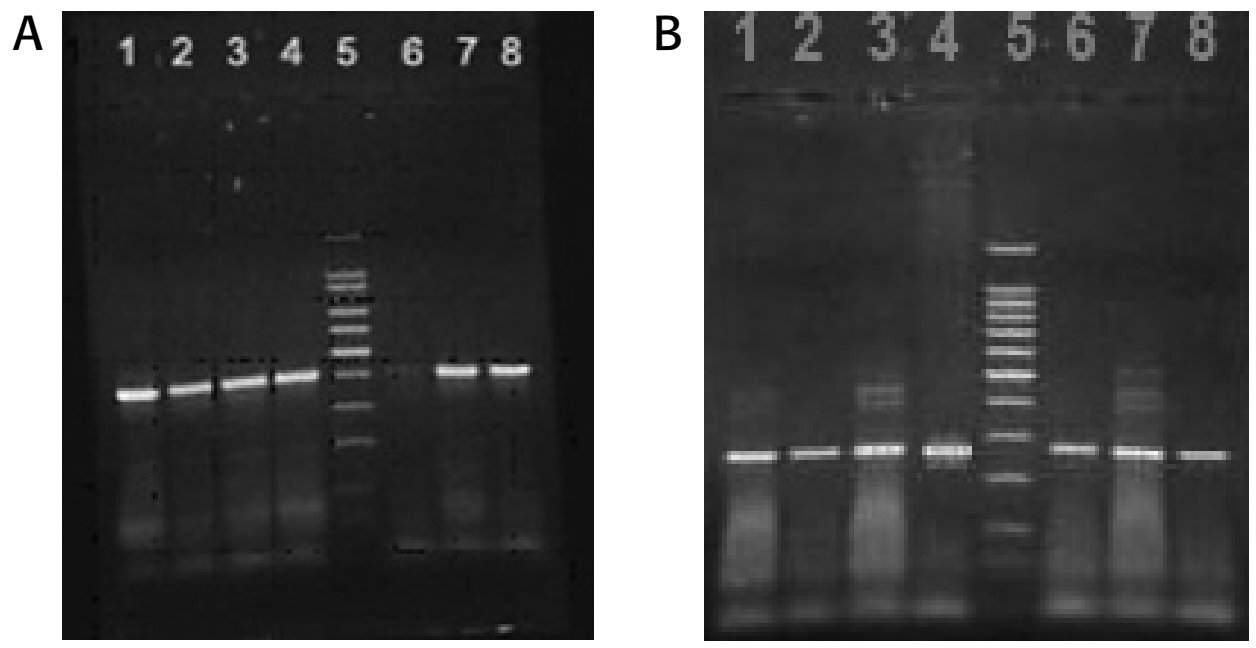

Figure 3: RT-PCR for Hsp-27 and $\beta_{2}$-microglobulin on MCF-7 cells. RT-PCR in MCF-7 cells grown on the following conditions. Channel 1: Control, Channel 2: CFE $2 \mu \mathrm{g} / \mathrm{L}$, Channel 3: CFE $20 \mu \mathrm{g} / \mathrm{L}$, Channel 4: CFE $200 \mu \mathrm{g} / \mathrm{L}$, Channel 5: DNA ladder (100 bP), Channel 6: CFE 2000 $\mu \mathrm{g} / \mathrm{L}$, Channel 7: Tamoxifen $480 \mathrm{ng} / \mathrm{mL}$, Channel 8: $\beta$ Estradiol 315 pM. Panel A: amplicons for Hsp27 (400 bp) and Panel B: amplicons for $\beta_{2}$-microglobulin (267 bp), used as constitutive control. 


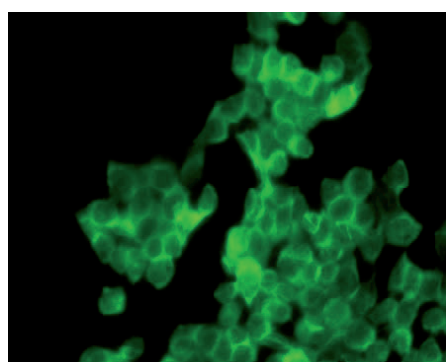

Control FITC 20X, 20 Seg

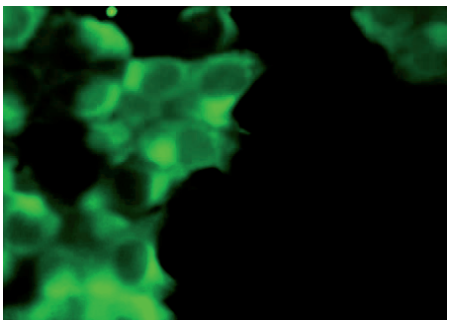

CFE $2 \mu \mathrm{g} / \mathrm{L}$ FITC $40 \mathrm{X}, 20 \mathrm{Seg}$

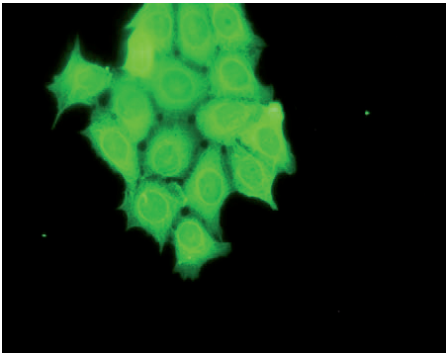

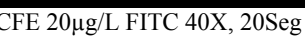

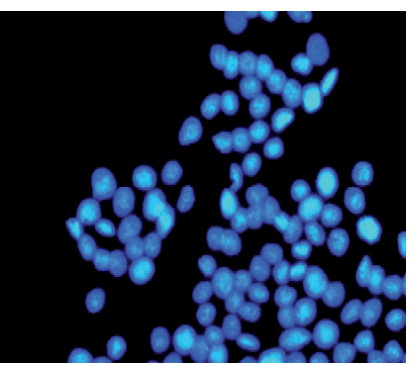

Control DAPI 20X, 450Mseg

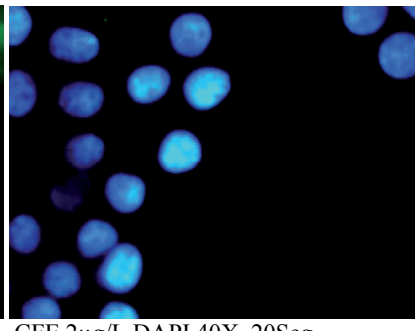

CFE $2 \mu \mathrm{g} / \mathrm{L}$ DAPI 40X, 20Seg

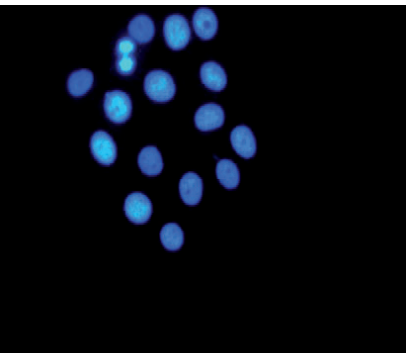

CFE 20 $\mu \mathrm{g} / \mathrm{L}$ DAPI 40X, 400Mseg

Figure 4: Hsp 27 detection by immunofluorescence. Immunofluorescence for MCF-7 cells grown in the following conditions: control media, CFE $2 \mu \mathrm{g} / \mathrm{L}$, CFE $20 \mu \mathrm{g} / \mathrm{L}$, CFE $200 \mu \mathrm{g} / \mathrm{L}$, CFE $2000 \mu \mathrm{g} / \mathrm{L}$, $\beta$-estradiol $315 \mathrm{pM}$ and tamoxifen $480 \mathrm{ng} / \mathrm{mL}$. The left column represents immunofluorescence utilizing a first antibody against Hsp-27 that was 1:50 and a secondary anti-goat-FITC antibody utilized at 1:100 dilutions. The right column represents the fluorescence of nuclei stained with DAPI for all conditions.
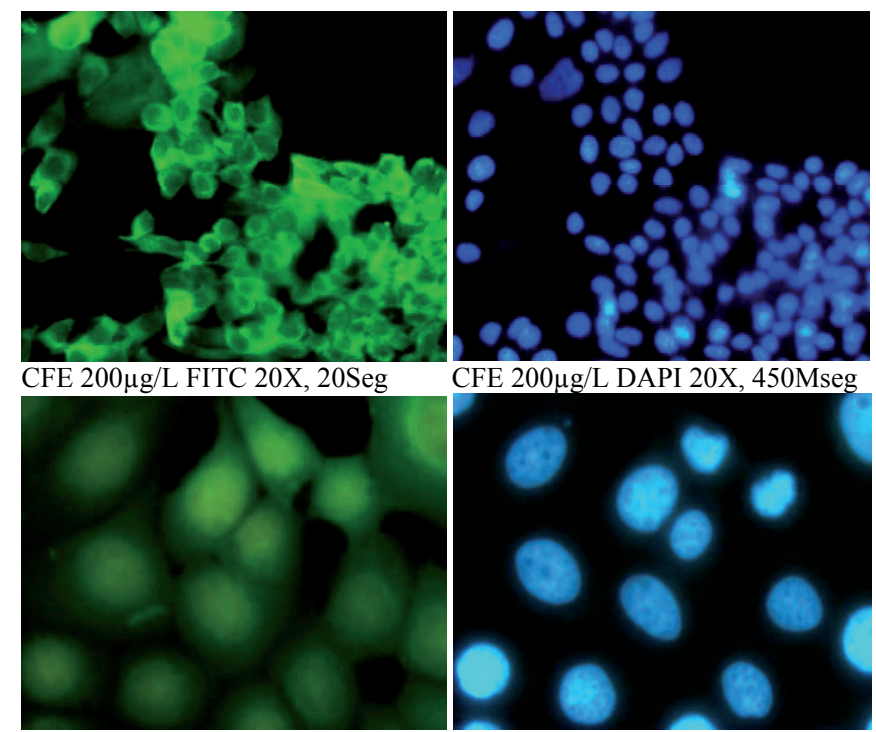

CFE 200ug/L DAPI 20X, 450Mseg

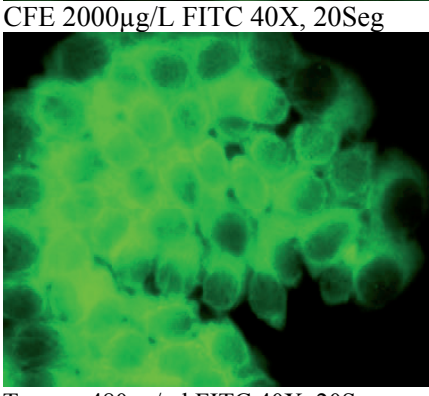

Tamox. 480ng/ml FITC 40X, 20Seg

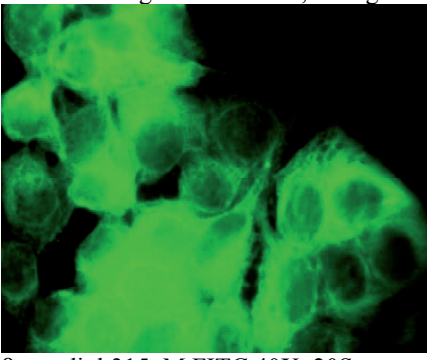

ßestradiol 315pM FITC 40X, 20Seg

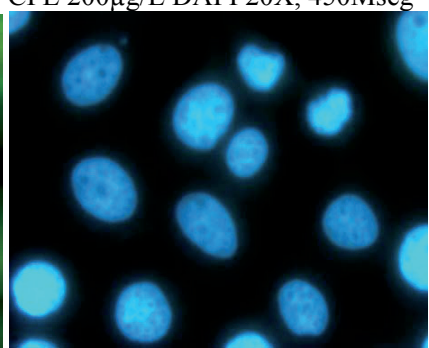

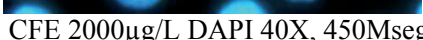

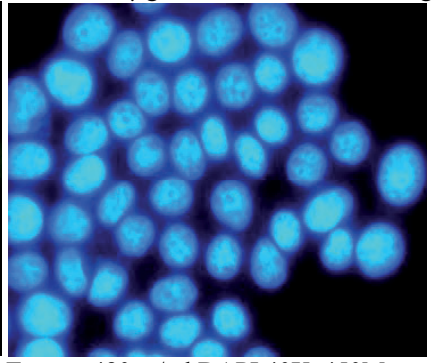

Tamox. 480ng/ml DAPI 40X, 450Mseg

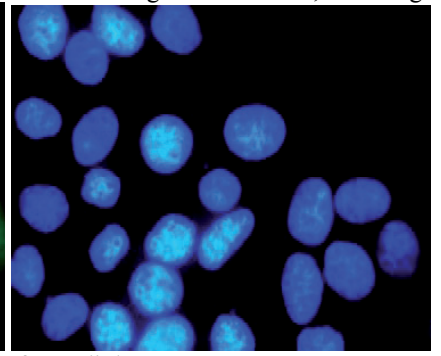

ßestradiol 315pM DAPI 40X, 450Mseg
A

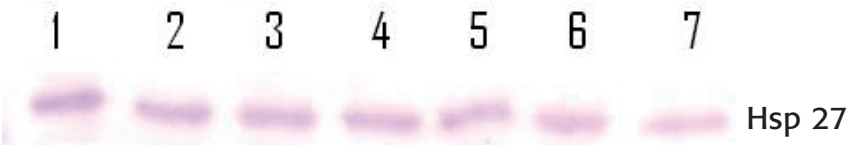

Actin
B

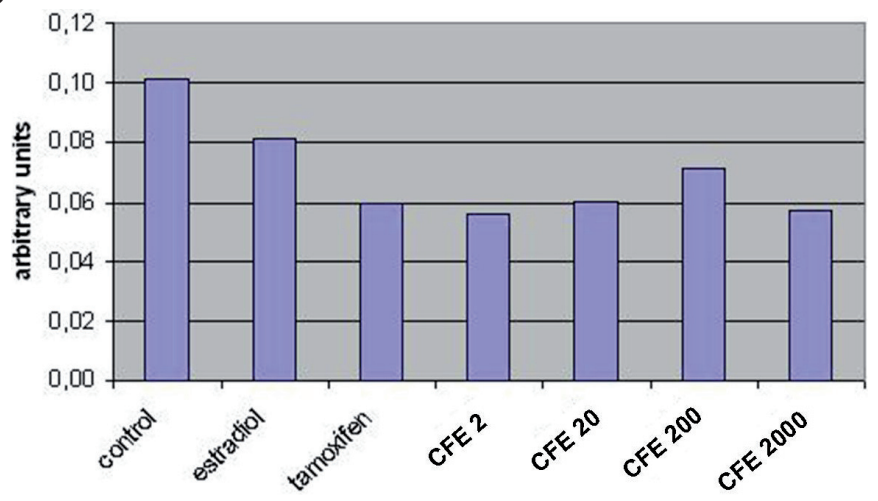

Figure 5: Hsp 27 detection by immunoblot. Panel A. Immunoblot for MCF-7 cells grown in the following conditions: channel 1: control media, channel 2: $\beta$-estradiol $315 \mathrm{pM}$, channel 3: tamoxifen $480 \mathrm{ng} / \mathrm{mL}$, channel 4: CFE $2 \mu \mathrm{g} / \mathrm{L}$, channel 5: CFE $20 \mu \mathrm{g} / \mathrm{L}$, channel 6: CFE $200 \mu \mathrm{g} / \mathrm{L}$, channel 7: CFE $2000 \mu \mathrm{g} / \mathrm{L}$. Anti-hsp-27 antibody was 1: 5,000 and anti-actin antibody was 1:5,000. In both cases the secondary antibody was donkey anti goat-AP 1: 10,000. Panel B. Histogram for the densitometry analysis of the electrophoretic bands. Results are shown as the rate of Hsp27 over actin signals. 
In addition, we report for the first time the study of Hsp-27 expression after MCF-7 cells were exposed to CFE. The stressful conditions characteristic of the tumors' microenvironment facilitate the expression of heat shock proteins. Increased expression of Hsp-27, proportional to the levels of estrogen receptors, has been detected in breast and ovarian cancer cell lines and primary tumors (Langdon et al., 1995, Porter et al., 1996). Moreover, Hsp-27 has been strongly associated with tumor aggressiveness due to several effects, such as apoptosis inhibition, immunosuppressant activity and drug resistance (Rane et al., 2003, Uozaki et al., 1997, Lee et al., 2007). In this study, MCF-7 cells were exposed to different concentrations of CFE and to other stimuli including $\beta$-estradiol and tamoxifen. When MCF-7 cells were stimulated with $\beta$-estradiol at $315 \mathrm{pM}$, which is within the physiological range for a premenopausal woman, the expressions of Hsp-27 mRNA and protein were detected by RT-PCR (Fig. 3, lane 8) and protein immnofluorescence (Fig. 4), as well as Western blot (Fig. 5A, lane 2), respectively. These results are consistent and expected according to the literature (Edwards et al., 1981, Porter et al., 1996).

It has been reported that exposure of MCF-7 cells to tamoxifen resulted in decreasing cell proliferation and cell cycle arrest in $G_{0} / G_{1}$ and $G_{2}$ phases (Ichikawa et al, 2008). Our results showed that it did not inhibit the Hsp-27 mRNA (Fig. 3, channel 7) or protein expression (Fig.4, Fig.5A) after treating MCF-7 cells with tamoxifen. This result was not expected, since tamoxifen is a known estrogen receptor antagonist in breast tissue. However, it is in agreement with previous research showing that certain antagonists of the estrogen receptor had transcriptional activity on the Hsp-27 gene (Porter el al, 2001). Some control experiments were performed with hydroxy-tamoxifen, a known in vivo metabolite of tamoxifen and showed no differences on Hsp-27 expression (result not shown).

Our results, upon stimulation using low concentrations of CFE $(2,20,200 \mu \mathrm{g} / \mathrm{L})$, showed Hsp-27 expression in both Hsp-27 mRNA (Fig. 3A, channels 2, 3, 4) and protein (Fig. 4, Fig.5A). It is suggested that the cytoplasmatic and perinuclear immunofluorescence signal in these cells could be explained by phosphorylated Hsp27 binding to denatured F-actin (Pivovarova et al., 2007) in these parts of the cell upon the stress induced by CFE. Similar results were obtained by Einbond et al (2008), but using actein. Actein has been reported producing stress and also inducing apoptosis in MCF-7 and MDA-MB45 cells. The mechanism of action used by the Hsp27 to protect the cytoskeleton, and therefore tumor cell survival, is still not sufficiently understood (Pivovarova et al., 2007).

With a higher concentration of CFE $(2,000 \mu \mathrm{g} / \mathrm{L})$, similar to that used in MCF-7 cells stimulated with C. racemosa (Zierau et al., 2002), no Hsp-27 mRNA or protein expression was detected by RT-PCR (Fig. 3A, channel 6), or protein immunofluorescence (Fig. 4). We speculate that at 2,000 $\mu \mathrm{g} / \mathrm{L}$ of CFE, Hsp-27 expression might be reduced, as well as its cytoprotective effect on MCF-7 cells. However, Western blot analysis using whole cell lysates showed protein expression at this CFE concentration (Fig. 5A). Previous publications have described the possibility that Hsp-27 translocates to the nucleus in some extension, which is in agreement with reports of Ciocca et al (1998) in clinical samples. More experiments will be needed to elucidate these interesting results, especially because the Hsp family and their transcription factors have been considered as a new gateway for cancer therapy since they are required for cell survival during tumor progression and metastasis (Volloch and Sherman 1999, Hoang et al 2000, Nylandsted et al 2000a,b, Jones et al 2004). Hsp 27 can be the target of antisense oligonucleotide therapies, which has resulted in increased apoptosis in human prostate cancer cells (So et al 2005) and also enhanced apoptosis and delayed progression of prostate tumors (Rocchi et al 2004). This is a promising result considering the association between tumor aggressiveness and Hsp-27 expression, which underscores the potential of the CFE as a new source of antineoplasic molecules. For this reason, it is also necessary to determine which CFE components are mediating its effect on Hsp-27. These might be the ones that are exclusive for Cimicifuga foetida, such as cimifugoside $\mathrm{H}-1$, cimicifugin or cimicifugin glucoside (He et al., 2006). We support this statement in unpublished results using Cimicifuga racemosa, which showed a different dose response effect on Hsp-27 protein expression.

\section{ACKNOWLEDGEMENTS}

This work was supported by grants from the Dirección de Investigación de la Universidad de Valparaíso, Chile (DIPUV $13 / 04$ and $05 / 06)$.

\section{REFERENCES}

BORRELLI F, ERNST E (2002) Cimicifuga racemosa: a systematic review of its clinical efficacy. Eur J Clin Pharmacol 58: 235-241.

CIOCCA DR, GREEN S, ELLEDGE RM, CLARK GM, PUGH R, RAVDIN P, LEW D, MARTINO S, OSBORNE CK (1998) Heat shock proteins Hsp27 and Hsp70: Lack of correlation with response to tamoxifen and clinical course of disease in estrogen receptor-positive metastatic breast cancer (A southwest oncology group study). Clin Cancer Res 5: 1263-1266.

CIOCCA DR, CALDERWOOD SK (2005) Heat shock proteins in cancer: diagnostic, prognostic, predictive, and treatment implications. Cell Stress Chaperones 10: 86-103.

CUBANO L, LEWIS ML (2001) Effect of vibrational stress and spaceflight on regulation of heat shock proteins hsp70 and hsp27 in human lymphocytes (Jurkat) J Leukocyte Biology 69: 755-761.

EDWARDS DP, ADAMS DJ, MCGUIRE WL (1981) Estradiol stimulates synthesis of a major intracellular protein in a human breast cancer cell line (MCF-7). Breast Cancer Res Treat 1: 209-223.

EINBOND LS, SHIMIZU M, XIAO MD, NUNTANAKORN P, LIM JT, SUZUI M, SETER C, PERTEL T, KENNELLY EJ, KRONENBERG F, WEINSTEIN IB (2004) Growth inhibitory activity of extracts and purified components of black cohosh on human breast cancer cells. Breast Cancer Res Treat 83: 221-231.

EINBOND LS, WEN-CAI Y, HE K, WU H, CRUZ E, ROLLER M, KRONENBERG F (2008) Growth inhibitory activity of extracts and compounds from Cimicifuga species on human breast cancer cells. Phytomedicine 15: 504-511.

FORTIN A, RAYBAUD-DIOGENE H, TETU B, DESCHENES R, HOUT J, LANDRY J (2000) Overexpression of the $27 \mathrm{kDa}$ heat shock protein is associated with thermoresistance and chemoresistance but not with radioresistance. Int J Radiat Oncol Biol Phys 46:1259-1266.

GAUBE F, WOLFL S, PUSCH L, KROLL TC, HAMBURGER M (2007) Gene expression profiling reveals effects of Cimicifuga racemosa (L.) NUTT. (black cohosh) on the estrogen receptor positive human breast cancer cell line MCF-7. BMC Pharmacol 7: 11- 29.

HE K, PAULI GF, ZHENG B, WANG H, BAI N, PENG T, ROLLER M, ZHENG Q (2006) Cimicifuga species identification by high performance liquid chromatography-photodiode array/mass spectrometric/ evaporative light scattering detection for quality control of black cohosh products. J Chromatogr A 1112: 241-254.

HOANG AT, HUANG J, RUDRA-GANGULY N, ZHENG J, POWELL WC, RABINDRAN SK, WU C, ROY-BURMAN P (2000) A novel association between the human heat shock transcription factor 1 (HSF1) and prostate adenocarcinoma. Am J Pathol 156: 857-864. 
HOSTANSKA K, NISSLEIN T, FREUDENSTEIN J, REICHLING J, SALLER R (2004a) Cimicifuga racemosa extract inhibits proliferation of estrogens receptor-positive and negative human breast carcinoma cell lines by induction of apoptosis. Breast Cancer Res Treat 84: 151-160.

HOSTANSKA K, NISSLEIN T, FREUDENSTEIN J, REICHLING J, SALLER $R$ (2004b) Evaluation of cell death caused by triterpene glycosides and phenolic substances from cimicifuga racemosa extract in human MCF-7 breast cancer cells. Biol Pharm Bull 27: 1970-1975.

HOSTANSKA K, NISSLEIN T, FREUDENSTEIN J, REICHLING J, SALLER R (2005) Apoptosis of human prostate androgen-dependent and -independent carcinoma cells induced by an isopropanolic extract of black cohosh involves degradation of cytokeratin (CK) 18. Anticancer Res 25: 139-147.

ICHIKAWA A, ANDO J, SUDA K (2008) G1 arrest and expression of cyclindependent kinase inhibitors in tamoxifen-treated MCF-7 human breast cancer cells. Hum Cell 21: 28-37.

JARRY H, THELEN P, CHRISTOFFEL V, SPENGLER B, WUTTKE W (2005) Cimicifuga racemosa extract BNO 1055 inhibits proliferation of the human prostate cancer cell line LNCaP. Phytomedicine 12: 178-182.

JONES EL, ZHAO MJ, STEVENSON MA, CALDERWOOD SK (2004) The 70 kilodalton heat shock protein is an inhibitor of apoptosis in cancer. Int J Hyperthermia 20: 835-849.

LAFFON B, PÁSARO E, MÉNDEZ J (2001) Effects of styrene-7,8-oxide over p53, p21, bcl-2 and bax expression in human lymphocyte cultures. Mutagenesis 16: 127-132.

LANGDON SP, RABIASZ GJ, HIRST GL, KING JB, HAWKINS RA, SMYTH JF, MILLER WR (1995) Expression of the heat shock protein Hsp27 in human ovarian cancer. Clin Cancer Res 1: 1603-1609.

LEE JH, SUN D, CHO KJ, KIM MS, HONG MH, KIM IK, LEE JS, LEE JH (2007) Overexpression of human $27 \mathrm{kDa}$ heat shock protein in laryngeal cancer cells confers chemoresistence associated with cell growth delay. J Cancer Res Clin Oncol 133: 37-46.

NYLANDSTED J, BRAND K, JAATTELA M (2000a) Heat shock protein 70 is required for the survival of cancer cells. Ann N Y Acad Sci 926: 122-125.

NYLANDSTED J, RHODE M, BRAND K, BASTHOLM L, ELLING F, JAATTELA M (2000b) Selective depletion of heat shock protein 70 (Hsp70) activates a tumor- specific death program that is independent of caspases and bypasses Bcl-2. Proc Natl Acad Sci USA 97: 7871-7876.

PARCELLIER A, SCHMITT E, BRUNET M, HAMMANN A, SOLARY E, GARRIDO C (2005) Small heat shock proteins Hsp27 and alpha Bcrystallin: cytoprotective and oncogenic functions. Antioxid Redox Signal 7: 404-413.

PIVOVAROVA AV, CHEBOTAREVA NA, CHERNIK IS, GUSEV NB, LEVITSKY DI (2007) Small heat shock protein Hsp27 prevents heat- induced aggregation of F-actin by forming soluble complexes with denatured actin. Febs Journal 274: 5937-5948.

PORTER W, WANG F, WANG W, DUAN R, SAFE S (1996) Role of estrogen receptor/Sp1 complexes in estrogen-induced heat shock protein 27 gene expression. Mol Endocrinol 10: 1371-1378.

PORTER W, WANG F, WANG W, DUAN R, QIN C, CASTRO-RIVERA E, KIM K, SAFE S (2001) Transcriptional activation of heat shock protein 27 gene expression by $17 \beta$-estradiol and modulation by antiestrogens and aryl hydrocarbon receptor agonists. J Mol Endocrinol 26: 31-42.

RANE MJ, PAN Y, SINGH S, POWELL DW, WU R, CUMMINS T, CHEN Q, MCLEISH KR, KLEIN JB (2003) Heat shock protein 27 controls apoptosis by regulating Akt activation. J Biol Chem 278: 27828-27835.

ROCCHI P, SO A, KOJIMA S, SIGNAEVSKY M, BERALDI E, FAZLI L, HURTADO-COLL A, YAMANAKA K, GLEAVE M (2004) Heat shock protein 27 increases after androgen ablation and plays a cytoprotective role in hormone-refractory prostate cancer. Cancer Res 64: 6595-6602.

SEIDLOVA-WUTTKE D, THELEN P, WUTTKE W (2006) Inhibitory effects of a black cohosh (Cimicifuga racemosa) extract on prostate cancer. Planta Medica 72: 521-526.

SKEHAN P, STORENG R, SCUDIERO D, MONKS A, MCMAHON J, VISTICA D, WARREN JT, BOKESCH H, KENNEY S, BOYD MR (1990) New colorimetric cytotoxity assay for anticancer-drug screening. J Natl Cancer Inst 82: 1107-1112.

SO A, ROCCHI P, GLEAVE M (2005) Antisense oligonucleotide therapy in the management of bladder cancer. Current Opinion in Urology 15: 320327.

SUN LR, QING C, ZHANG YL, JIA SY, LI ZR, PEI SJ, OIU MH, GROSS ML, QIU SX (2007) Cimicifoetisides A and B, two cytotoxic cycloartane triterpenoid glycosides from the rhizomes of Cimicifuga foetida inhibit proliferation of cancer cells. Beilstein J Org Chem 3: 3-8

TIAN Z, PAN RL, CHANG Q, SI J, XIAO PG, WU E (2007) Cimicifuga foetida extract inhibits proliferation of hepatocellular cells via induction of cell cycle arrest and apoptosis. J Ethnopharmacol 114: 227-233.

UOZAKI H, HORIUCHI H, ISHIDA T, IIJIMA T, IMAMURA T, MACHINAMI R (1997) Overexpression of resistance-related proteins (metallothioneins, glutathione-S-transferase pi, heat shock protein 27 and lung resistance-related protein) in osteosarcoma. Relationship with poor prognosis. Cancer 79: 2336-2344.

VOLLOCH VZ, SHERMAN MY (1999) Oncogenic potential of Hsp 72. Oncogene 18: 3648-3651.

ZIERAU O, BODINET C, KOLBA S, WULF M, VOLLMER G (2002) Antiestrogenic activities of Cimicifuga racemosa extracts. J Steroid Biochem Mol Biol 80:125-130. 
